\title{
Epidemiology of foodborne Norovirus outbreaks in Catalonia, Spain
} Ana Martinez ${ }^{1}$, Angela Dominguez ${ }^{* 2,3,1}$, Nuria Torner ${ }^{3,1}$, Laura Ruiz ${ }^{1}$, Neus Camps ${ }^{1}$, Irene Barrabeig1, Cesar Ariass ${ }^{1}$, Josep Alvarez ${ }^{1}$, Pere Godoy ${ }^{1,3}$, Pilar Jorgina Balaña1, Analia Pumares ${ }^{1}$, Rosa Bartolome ${ }^{4}$, Dolors Ferrer ${ }^{5}$, Unai Perez ${ }^{6}$, Rosa Pinto ${ }^{6}$, Javier Buesa ${ }^{7}$ and The Catalan Viral Gastroenteritis Study Group

\author{
Address: ${ }^{1}$ Department of Health, Autonomous Government of Catalonia, Barcelona, Spain, ${ }^{2}$ Department of Public Health, University of \\ Barcelona, Spain, ${ }^{3}$ CIBER Epidemiology and Public Health (CIBERESP), Spain, ${ }^{4}$ Department of Microbiology, Hospital Universitari Vall d'Hebron, \\ Barcelona, Spain, 5 Public Health Laboratory, Public Health Agency of Barcelona, Spain, ${ }^{6}$ Enteric Virus Laboratory, University of Barcelona, Spain \\ and ${ }^{7}$ Microbiology Department, University of Valencia, Spain \\ Email: Ana Martinez - a.martinez@gencat.cat; Angela Dominguez* - angela.dominguez@ub.edu; Nuria Torner - nuria.torner@gencat.cat; \\ Laura Ruiz - laura.ruiz@gencat.cat; Neus Camps -ncamps@gencat.cat; Irene Barrabeig - ibarrabeig@catsalut.cat; \\ Cesar Arias - uverc@sapcll.scs.es; Josep Alvarez - jalvarezr@gencat.cat; Pere Godoy - pere.godoy@gencat.cat; Pilar \\ Jorgina Balaña - PILARJ.BALANA@gencat.cat; Analia Pumares - apumares@gencat.cat; Rosa Bartolome - rbartolo@vhebron.net; \\ Dolors Ferrer - dferrer@aspb.cat; Unai Perez - uperez@ub.edu; Rosa Pinto - rpinto@ub.edu; Javier Buesa - javier.buesa@uv.es; The Catalan Viral \\ Gastroenteritis Study Group - angela.dominguez@ub.edu \\ * Corresponding author
}

Published: 14 April 2008

BMC Infectious Diseases 2008, 8:47 doi:10.1 186/147/-2334-8-47
Received: 29 October 2007

Accepted: 14 April 2008

This article is available from: http://www.biomedcentral.com/I47I-2334/8/47

(C) 2008 Martinez et al; licensee BioMed Central Ltd.

This is an Open Access article distributed under the terms of the Creative Commons Attribution License (http://creativecommons.org/licenses/by/2.0), which permits unrestricted use, distribution, and reproduction in any medium, provided the original work is properly cited.

\begin{abstract}
Background: Noroviruses are one of the principal biological agents associated with the consumption of contaminated food. The objective of this study was to analyse the size and epidemiological characteristics of foodborne outbreaks of gastroenteritis in Catalonia, a region in the northeast of Spain.

Methods: In all reported outbreaks of gastroenteritis associated with food consumption, faecal samples of persons affected were analysed for bacteria and viruses and selectively for parasites. Study variables included the setting, the number of people exposed, age, sex, clinical signs and hospital admissions. The study was carried out from October 2004 to October 2005.

Results: Of the 18I outbreaks reported during the study period, 72 were caused by Salmonella and 30 by norovirus (NoV); the incidence rates were 14.5 and 9.9 per 100,000 person-years, respectively. In 50\% of the NoV outbreaks and $27 \%$ of the bacterial outbreaks $(p=0.03)$ the number of persons affected was $\geq 10$; $66.7 \%$ of NoV outbreaks occurred in restaurants; no differences in the attack rates were observed according to the etiology. Hospitalizations were more common $(p=0.03)$ in bacterial outbreaks $(8.6 \%)$ than in NoV outbreaks $(0.15 \%)$. Secondary cases accounted for $4 \%$ of cases in NoV outbreaks compared with $0.3 \%$ of cases in bacterial outbreaks $(p<0.00$ I)

Conclusion: Norovirus outbreaks were larger but less frequent than bacterial outbreaks, suggesting that underreporting is greater for NoV outbreaks. Food handlers should receive training on the transmission of infections in diverse situations. Very strict control measures on handwashing and environmental disinfection should be adopted in closed or partially-closed institutions.
\end{abstract}




\section{Background}

Diseases resulting from the consumption of contaminated food cause a considerable disease burden in developed countries [1], and thus it is important to determine their etiology and food vehicles. Although there are difficulties in associating a specific food with the appearance of cases or outbreaks of gastroenteritis [2], reports agree that noroviruses (NoV) (formerly Norwalk-like viruses) are one of the foremost biological agents involved in cases of gastroenteritis associated with food consumption [3].

The stability of NoV in various environmental conditions means that they can remain infectious in frozen and refrigerated food and even in food heated to $60^{\circ} \mathrm{C}$ for 30 minutes [4], which explains why they can be easily transmitted by foods contaminated by contact with human faecal matter or by unhygienic food handling [5].

The infective dose of NoV is very low: new infections may be produced by person-to-person transmission of very small amounts of virus. Therefore, secondary cases usually appear in foodborne outbreaks caused by a single exposure [6].

The available evidence on foodborne gastroenteritis outbreaks due to $\mathrm{NoV}$ is based on national and international public health activities [6,7]. Although most laboratories are equipped to analyse bacterial processes, few are able to make a diagnosis of viral causes of gastroenteritis and, therefore, confirmation of a possible viral cause of gastroenteritis is not always sought [8].

Analysis of the official statistics provided by different health authorities is frequently partial and their interpretation is complex [9].

Studies of the epidemiology of foodborne NoV outbreaks in each community are necessary, even though they represent only a part of the real situation due to clinical and epidemiological underreporting and laboratory difficulties. Knowledge of outbreaks and the distribution of specific strains is also necessary to carry out interventions at a local level that allow the prevention of new outbreaks $[6,10]$.

The objective of this study was to determine the size and epidemiological characteristics of foodborne outbreaks due to NoV in Catalonia between October 2004 and October 2005 and compare them with bacterial outbreaks.

\section{Methods}

We carried out a prospective study of foodborne outbreaks occurring between 15 October 2004 and 30 Octo- ber 2005 in Catalonia, a region in the northeast of Spain, with a population of 6.9 million.

A foodborne outbreak was defined as two or more cases with similar symptoms resulting from the ingestion of a common food when this was confirmed by epidemiological and/or microbiological analysis.

When an outbreak was reported to public health authorities, a routine investigation was carried out to determine the characteristics of the cases and the possible food involved using a standardized questionnaire. Likewise, clinical and food samples were collected for laboratory analysis to identify the causal agent. In addition to standard microbiological tests to rule out bacterial and parasitic causes, enzyme linked immunosorbent assay and RT-PCR techniques were carried out on faecal samples of cases, and of food handlers when the outbreak was not limited to the family setting, to detect viruses.

Stool samples were plated on selective and differential media to study Salmonella (MacConkey agar, SalmonellaShigella agar, Xylose-Lysine-Desoxycholate agar and Selenite enrichment broth), Shigella (MacConkey agar and Salmonella-Shigella agar), Shiga toxin-producing strains of O157:H7 Escherichia coli (MacConkey agar with sorbitol), Yersinia (Cefsulodin-Irgasan-Novobiocin, CIN agar), Campylobacter (Charcoal agar), Vibrio (Thiosulfate Citrate Bile salt Sucrose, TCBS agar) and Aeromonas spp (Pseudomonas-Aeromonas agar with 100,000 IU per litre of Penicillin G, GSP agar).

In outbreaks where a parasitic infection was suspected, the diagnosis was established by direct microscopic examination or after concentration of preserved stool (Merthiolate-iodine-formalin and $10 \%$ formalin) to determine the presence of ova, trophozoites or cysts. Cryptosporidium oocysts were examined by stained fecal materials (Auramine and Ziehl-Neelsen stains).

Enzyme immunoassays for NoV genogroups I and II (IDEIA $^{\mathrm{TM}} \mathrm{NoV}$, DakoCytomation), rotavirus group A (IDV Rotavirus-96.Izasa), astrovirus (IDEIA ${ }^{\mathrm{TM}}$ Astrovirus, DakoCytomation) and adenovirus serotypes 40 and 41 (IDV Adenovirus-96.Izasa) and RT-PCR were performed.

For NoV, RT-PCR primers designed for partial RNA polymerase region (ORF1) were used: NVp110 (5'-ACD ATY TCA TCA TCA CCA TA-3') for RT and JV12 (5'-ATA CCA CTA TGA TGC AGA TTA-3'), and JV13 (5'-TCA TCA TCA CCA TGA AAA GAC-3')for PCR [11]. For rotavirus, the primers used were VP6-3 (5'-GCT TTA AAA CGA AGT CTT CAA C-3') and VP6-4 (5'-GGT AAA TTA CCA ATT CCT CCA G-3') [12]. The primers used for adenovirus were hexAA1885 (5'-GCCGCAGTGGTCTTACATGCA- 
CATC-3') and hexAA1913 (5'-CAGCACGCCGCGGATGTCAAAGT-3'), which amplify a 301 bp fragment within the hexon region of the adenovirus genome [13]. For the genogroup A astrovirus, primer set A1 (5'-CCTGCCCCGAGAACAACCAAGC-3') and A2 (5'-GTAAGATTCCCAGATTGGTGC-3') from the hypervariable region of the ORF1a of the astrovirus genome was used [14] and for the detection of genogroup B astrovirus, primer set A1bis (5'-CCTGCCCCCCGTATAATTAAAC-3') and A2bis (5'ATAGGACTCCCATATAGGTGC-3') [15]. PCR products were detected in a $2 \%$ ethidium bromide-stained agarose gel and purified with the QIAquick PCR Purification Kit (QIAGEN, Hilden, Germany).

Norovirus genotyping systems and an automated sequencer (Applied Biosystems) was performed by sequencing the amplimers with the JV12 and JV13 primers using the ABI PRISM Big Dye Terminator Cycle Sequencing kit (Applied BiosBI PRISM 3700) [16]. Likewise, foods suspected of being involved in the outbreak were analysed when some remained.

An outbreak was considered as being caused by NoV if one or more samples were PCR positive for $\mathrm{NoV}$ or if cases fulfilled Kaplan's criteria [17].

The variables analysed included the agent, setting of the outbreak, date of appearance of the first case, number of people exposed, number of cases, age, sex, symptoms and hospitalization. In non-familial outbreaks, it was determined whether the case was primary or secondary. A secondary case was defined as someone who had not consumed the suspected food and in whom the onset of symptoms occurred after the maximum incubation period of the causal agent.

\section{Statistical Analysis}

Differences between medians were compared using the Mann-Whitney U test. Differences between proportions were compared using the $\mathrm{X}^{2}$ test or Fisher's exact test. The tests were two-tailed. An alpha level $=0.05$ was considered statistically significant. Incidence rates and their 95\% confidence intervals (CI) were calculated using the 2005 voter's list, assuming a Poisson distribution. Only outbreaks occurring in a natural year (15 October $2004-14$ October 2005) were considered for the seasonal distribution and calculation of the incidence rates.

\section{Results}

In the study period there were 181 foodborne gastroenteritis outbreaks due to all causes, of which Salmonella (72 outbreaks, 40\%) and NoV (30 outbreaks, 17\%) were the most-frequent (Table 1). Of the 30 foodborne NoV outbreaks, $20(66.7 \%)$ occurred in restaurants, $6(20 \%)$ in families, $2(6.7 \%)$ in residential nursing homes, $1(3.3 \%)$ in a school and 1 in a summer camp (3.3\%). The number of samples analyzed was 1 to 3 in 10 outbreaks, 4 to 9 in 11 outbreaks and 10 or more in 8 outbreaks. There was only one NoV outbreak with no samples. NoV was identified as the sole agent in one or more samples from cases in 22 outbreaks and there was a mixed etiology in 3 outbreaks (with adenovirus, Salmonella and Vibrio parahaemolyticus, respectively); in the other 5 outbreaks, Kaplan's criteria were fulfilled. The genotype was determined In 10 outbreaks; 8 were genotype GGII.4 (Bristol/1993/UK) and 2 were GGII.2 (Melksham/1994/UK).

A total of 741 people were affected in the 30 NoV outbreaks and 1018 in 86 bacterial outbreaks. The incidence rates per 100,000 person-years of the cases associated with outbreaks were 9.9 (95\% CI 9.2-10.7) and 14.5 (95\% CI 13.6-15.4), respectively.

Although all cases were primary in most of the non-family outbreaks, in $7 \mathrm{NoV}$ outbreaks a total of 27 secondary cases were recorded (3.8\%); in bacterial outbreaks only 2 secondary cases were detected $(0.3 \%)$, both in the same outbreak (Table 2). The median time from the onset of the outbreaks until reporting of secondary cases was 48-72 hours.

The median age of cases was $\leq 15$ years in $10 \%$ of NoV outbreaks and $6 \%$ of bacterial outbreaks, $16-59$ years in $83 \%$ and $87 \%$, respectively and $\geq 60$ years in $7 \%$ in both groups. There were no significant differences between the gender distribution of NoV outbreaks (51.2\% male and

Table I: Distribution of foodborne outbreaks according to etiology. Catalonia, 15 October 2004 - 30 October 2005

\begin{tabular}{lll}
\hline Etiology & Number of outbreaks (\%) & Number of persons affected (\%) \\
\hline Salmonella & $72(39.8)$ & $605(29.4)$ \\
NoV & $30(16.6)$ & $741(35.0)$ \\
Other bacteria* & $14(7.7)$ & $413(20.1)$ \\
Vegetable toxins & $16(8.8)$ & $572.7)$ \\
Other toxic substances & $12(6.6)$ & $39(1.9)$ \\
Unknown & $37(20.5)$ & $263(12.8)$ \\
Total & $\mathbf{1 8 1 ( 1 0 0 . 0 )}$ & $\mathbf{2 1 1 8 ( 1 0 0 . 0 )}$ \\
\hline
\end{tabular}

* Staphylococcus aureus (6), Clostridium perfringens (6), Campylobacter jejuni (I), Streptococcus pyogenes (I). 
Table 2: Distribution of primary and secondary cases in the NoV and bacterial foodborne outbreaks according to setting.* Catalonia, 15 October 2004 - 30 October 2005

\begin{tabular}{|c|c|c|c|c|c|c|}
\hline \multirow[b]{2}{*}{ Setting } & \multicolumn{3}{|l|}{ NoV outbreaks } & \multicolumn{3}{|c|}{ Bacterial outbreaks } \\
\hline & Primary cases & Secondary cases & Total * & Primary cases & Secondary cases & Total * \\
\hline Restaurants & 499 & 6 & 505 & 298 & - & 298 \\
\hline Residential nursing homes & 7 & 5 & 12 & 7 & - & 7 \\
\hline Hospitals & - & - & - & 25 & 2 & 27 \\
\hline Schools & 129 & 14 & 143 & 306 & - & 306 \\
\hline Summer camps & 38 & 2 & 40 & - & - & - \\
\hline Cake shops & - & - & - & 20 & - & 20 \\
\hline All outbreaks & 673 & 27 & 700 & 656 & 2 & 658 \\
\hline
\end{tabular}

*Family outbreaks excluded

Table 3: Clinical characteristics of NoV and bacterial outbreaks. Catalonia, I5 October 2004 - 30 October 2005

\begin{tabular}{|c|c|c|c|}
\hline & NoV outbreaks & Bacterial outbreaks & $p$ value \\
\hline No. outbreaks & 30 & 86 & \\
\hline No. cases & 741 & 1018 & \\
\hline Size of outbreak (median and range) & $8.5(2-174)$ & $5.0(2-123)$ & $0.029 a$ \\
\hline Attack rate (median) & 0.66 & 0.70 & $0.091^{a}$ \\
\hline Abdominal pain (\%) & 81.5 & 79.6 & $0.34 \mathrm{~b}$ \\
\hline Vomiting (\%) & 59.0 & 39.0 & $<0.001 b$ \\
\hline Diarrhea (\%) & 68.5 & 87.0 & $<0.001 b$ \\
\hline Nausea (\%) & 62.2 & 41.2 & $<0.001 b$ \\
\hline Fever (\%) & 42.0 & 52.4 & $<0.001 b$ \\
\hline Hospitalizations (\%) & 0.15 & 8.6 & $<0.001 b$ \\
\hline
\end{tabular}

a Mann-Whitney U; ${ }^{b} \chi^{2}$

$48.8 \%$ female) and bacterial outbreaks (52.5\% male and $47.5 \%$ female). The most frequent symptoms are shown in Table 3.

The size of the outbreaks ranged between 2 and 174 in NoV outbreaks and between 2 and 123 in bacterial outbreaks. In $50 \%$ of the NoV outbreaks and $27 \%$ of the bacterial outbreaks $(p=0.03)$ the number of cases was $\geq 10$. In $70 \%$ of the NoV outbreaks and $74 \%$ of the bacterial outbreaks the attack rate was $>50 \%$. Hospitalization occurred in one case in the viral outbreaks $(0.15 \%)$ and in 87 cases in bacterial outbreaks (8.6\%), with the difference being statistically significant $(\mathrm{p}<0.001)$ (Table 3$)$.

No seasonal pattern was observed in NoV outbreaks, while bacterial outbreaks showed an increase between June and October (Figure 1).

In the $17 \mathrm{NoV}$ outbreaks in which the food vehicle was determined by epidemiological analysis, the most common vehicles were fish, and more specifically, bivalve molluscs ( 8 outbreaks, 26.7\%), pastries (3 outbreaks, $10 \%$ ) and vegetables ( 2 outbreaks; $6.6 \%$ ); in the bacterial outbreaks, these figures were $2.3 \%, 3.5 \%$ and $0 \%$, respectively, with only the differences for fish and vegetables being statistically significant. Foods purchased in cake shops were more frequently involved in NoV outbreaks $(10 \%)$ than in bacterial outbreaks $(3.5 \%)$ although the differences were not statistically significant (Table 4). Laboratory analysis of foods was possible in 9 of the $30 \mathrm{NoV}$ outbreaks, although the virus was not detected in any outbreak; in 11 of the 86 bacterial outbreaks, the causal agent in the food was confirmed.

Stool samples from food handlers were analysed in 23 of $30 \mathrm{NoV}$ outbreaks $(76.7 \%$ ) and one or more samples were positive in 17 . The possible involvement of food handlers was detected by investigation in 13 outbreaks (43\%) but was confirmed by molecular epidemiology in only one outbreak. Faecal samples from food handlers were analyzed in 30 of 86 bacterial outbreaks (34.9\%) and the investigation confirmed the implication of a food handler as the source in 7 outbreaks $(8.1 \%)$ by microbiology (matching types).

\section{Discussion}

The results of this study emphasize the importance of foodborne transmission in gastroenteritis outbreaks due to $\mathrm{NoV}$. 


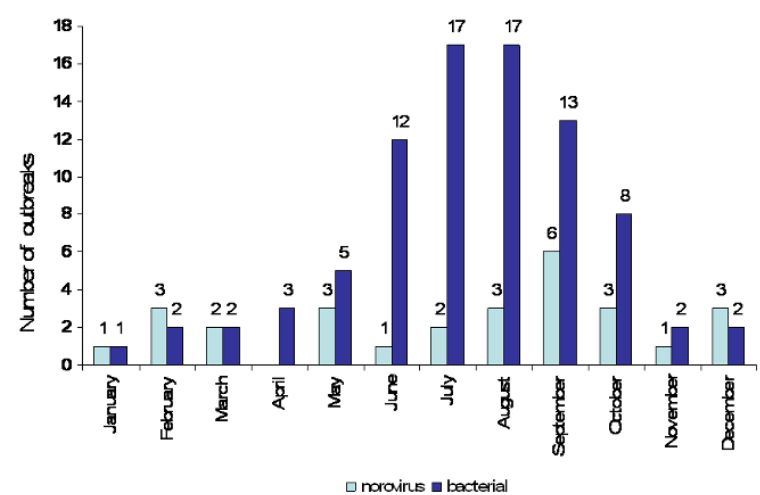

Figure I

Monthly distribution of foodborne outbreaks. I 5 October 2004 - 14 October 2005.

In this study, NoV was the second etiologic agent (30 outbreaks), only preceded by Salmonella (72 outbreaks). This is in agreement with other reports $[8,18]$, although some studies have found NoV to be the first cause of foodborne outbreaks [3,19-21]. The incidence rate of the NoV cases associated with outbreaks was 9.9 per 100,000 personyears, less than the 15.6 found by Lindqvist et al in Sweden [21].

Widdowson et al [18] found that 25\% of bacteria-negative outbreaks were not analyzed to detect viral causes, but this type of information is not normally available. In this study, all reported foodborne outbreaks were studied, searching first for bacteria and selectively for parasites and, if these were negative, for viruses. NoV outbreaks involved more cases, but less febrile cases and hospitalizations, showing that NoV outbreaks were less severe than bacterial outbreaks.

Although reported viral outbreaks were larger than bacterial outbreaks, the attack rates were similar, suggesting that smaller viral outbreaks are not reported. Cowden et al [22] in England found that underreporting of NoV was one hundred times greater than for Salmonella and 30 times greater than for Campylobacter.

In contrast with bacterial outbreaks, no seasonality was observed in NoV outbreaks. Some reports have found no seasonality in regard to NoV infection [22,23], while others have found an increase in winter in outbreaks involving person-to-person transmission [10], but not in foodborne outbreaks [24].
In this study, the food implicated was identified in only $57 \%$ of NoV outbreaks compared with $80 \%$ of bacterial outbreaks. In the United States, a 2002 study found levels of $47 \%$ and $76 \%$, respectively [19], but other studies show results similar to ours [18]. With the exception of bivalve molluscs, laboratory techniques to detect NoV in foods still have a very low sensitivity $[20,25]$.

The involvement of a food handler was suspected in $43 \%$ of NoV outbreaks, although the involvement was identified by molecular epidemiology in only one outbreak. Faecal samples should be routinely collected from patients and food handlers involved in the preparation of the foods consumed in order to demonstrate their involvement.

In our study, 27 of the 715 (3.8\%) people affected by NoV in non-family outbreaks were secondary cases, a ten-fold greater proportion than in bacterial outbreaks. Some reports of foodborne NoV outbreaks mention secondary cases [25-27], but their frequency is not clear $[6,27,28]$. As the incubation period of $\mathrm{NoV}$ infections is very short, cases may occur from contact with an infected person rather than from consumption of the food and, therefore, the number of secondary cases detected should be considered inferior to the real number. Research into whether cases in foodborne outbreaks are primary or secondary should be enhanced.

Most secondary cases detected corresponded to residential nursing homes (45\%) and schools (10\%), where close contact is the norm. It is established that up to $30 \%$ of infected people continue to shed the virus for three weeks [29]. Therefore, when a gastroenteritis outbreak of viral etiology is suspected, strict measures with respect to handwashing and disinfection of surfaces should immediately be adopted and compliance checked [30-32].

The main limitations of this study were the small number of samples available to diagnose the outbreaks and the passive nature of the reporting on which the study was based.

Although the means for laboratory diagnosis are available, it is not always possible to obtain the minimum four positive samples necessary to attribute the outbreak to NoV $[31,33,34]$. In this study we considered that one sample positive for NoV was sufficient if tests for bacteria and parasites were negative and the clinical signs and epidemiology were compatible [17]. A recent study [35] shows that the number of samples is less important for NoV outbreak diagnosis when RT-PCR techniques are used (as in the present study) than when only ELISA techniques are used. 
Table 4: Distribution of foods involved in NoV and bacterial outbreaks. Catalonia, I 5 October 2004 - 30 October 2005

\begin{tabular}{llll}
\hline & NoV outbreaks & Bacterial outbreaks & P value * \\
\hline Mayonnaise and similar & 0 & $27(31.4)$ & 0.005 \\
Other products containing egg & $2(6.7)$ & $19(22.1)$ & 0.51 \\
Fish and seafood & $8(26.7)$ & $2(2.3)$ & $<0.0001$ \\
Meat/sausage & $1(3.3)$ & $6(7.0)$ & 1.0 \\
Vegetables & $2(6.6)$ & 0 & 0.04 \\
Fowl & 0 & $3(3.5)$ & 1.0 \\
Cake shops & $3(10.0)$ & $3(3.5)$ & 0.06 \\
Others & $1(3.3)$ & $9(10.5)$ & 0.67 \\
Unknown & $13(43.3)$ & $17(19.8)$ & 0.003 \\
\hline
\end{tabular}

*Fisher test calculated comparing each food with respect to all foods involved

The passive surveillance system used during the study period may have resulted in less outbreaks being studied than really occurred. However, it is unlikely that this influenced the comparison between viral and bacterial outbreaks since, once the reports were received, the activities carried out were the same.

\section{Conclusion}

In this study, NoV was the second causal agent of foodborne outbreaks after Salmonella and NoV outbreaks were larger than bacterial outbreaks, suggesting greater underreporting and, consequently, draw-backs in the investigation of NoV outbreaks. Given that the NoV has a human reservoir, a very low infective dose and prolonged persistence in the environment, food handlers should be aware of how they can transmit the infection in different situations and receive appropriate preventive training [5]. In order to avoid secondary cases, when a foodborne outbreak of viral gastroenteritis in closed or partially-closed institutions is suspected, rapid control measures should be adopted, with an emphasis on handwashing and correct disinfection of environmental surfaces [32].

\section{Abbreviations}

NoV: Norovirus

RT-PCR: Reverse transcription polymerase chain reaction

\section{CI: Confidence Interval}

\section{Competing interests}

The author(s) declare that they have no competing interests.

\section{Authors' contributions}

$\mathrm{AD}$ and $\mathrm{AM}$ designed the study and drafted the manuscript. NT participated in the design and coordination and helped to draft the manuscript. LR performed the statistical analysis. RB, UP, RP, DF, and JB performed the microbiological analysis, IB, NC, JA, CA, PG, JPB, AP participated in the acquisition of outbreak data. All authors read and approved the final manuscript.

\section{Acknowledgements}

We are grateful for the collaboration of the physicians reporting outbreaks and the technicians of the Epidemiological Surveillance Units of the Department of Health of the Generalitat of Catalonia and the Public Health Agency of Barcelona. This work was supported by a grant from the Fondo de Investigaciones Sanitarias (Project $n^{\circ}$ PI 030877) Instituto Carlos III, Madrid, Spain.

The other members of the Catalan Viral Gastroenteritis Study Group are Glòria Carmona, Neus Cardeñosa (Department of Health, Barcelona, Spain), Maria Rosa Sala, Ariadna Rovira, Ignasi Parrón and Caritat Planas (Department of Health, Territorial Services of Barcelona, Spain), Nuria Follia and Maria Asunción Company (Department of Health, Territorial Service of Girona, Spain), Miquel Alseda, Joan Torres and Antoni Artigues (Department of Health, Territorial Service of Lleida, Spain), Sofia Minguell (Department of Health, Territorial Service of Tarragona, Spain), Mercedes de Simón (Laboratory of the Public Health Agency of Barcelona, Spain), Albert Bosch (Enteric Virus Laboratory. University of Barcelona, Spain), Gemma Codina (Microbiology Service, Vall d'Hebron Hospital, Barcelona Spain), Jesús Rodríguez and Rebeca Montava (Microbiology Department. University of Valencia, Spain).

\section{References}

I. Mead PS, Slutsker L, Dietz V, McCaig LF, Bresee JS, Shapiro C, Griffin PM, Tauxe RV: Food-related illness and death in the United States. Emerg Infect Dis 1999, 5:607-625.

2. Batz MB, Doyle MP, Morris G Jr., Painter J, Singh R, Tauxe RV, Taylor MR, Lo Fo Wong DM: Attributing illness to food. Emerg Infect Dis 2005, II:993-999.

3. Hedberg CW, Smith SJ, Kirkland E, Radke V, Jones TF, Selman CA: Systematic environmental evaluations to identify food safety differences between outbreak and nonoutbreak restaurants. J Food Prot 2006, 69:2697-2702.

4. Cliver DO, Matsiu SM, Casteel M: Infections with viruses and prions. In Foodborne Infections and Intoxications 3rd edition. Edited by: Riemann HP and Cliver DO. Amsterdam, Elsevier; 2006:367-448.

5. de Wit MA, Widdowson MA, Vennema H, de BE, Fernandes T, Koopmans M: Large outbreak of norovirus: the baker who should have known better. J Infect 2007, 55: I88-193.

6. Koopmans $M$, Vennema $H$, Heersma $H$, van Strien E, van Duynhoven Y, Brown D, Reacher M, Lopman B: Early identification of common-source foodborne virus outbreaks in Europe. Emerg Infect Dis 2003, 9: I | 36- I | 42.

7. Sanchez-Fauquier A, Wilhelmi I, Roman E, Colomina J, Montero V, Negredo A: Surveillance of human calicivirus in Spain. Emerg Infect Dis 2005, I I: I327-I329. 
8. Jones TF, Imhoff B, Samuel M, Mshar P, McCombs KG, Hawkins M, Deneen V, Cambridge M, Olsen SJ: Limitations to successful investigation and reporting of foodborne outbreaks: an analysis of foodborne disease outbreaks in FoodNet catchment areas, 1998-1999. Clin Infect Dis 2004, 38 Suppl 3:S297-S302.

9. Lopman B, van Duynhoven Y, Hanon FX, Reacher M, Koopmans M, Brown D: Laboratory capability in Europe for foodborne viruses. Euro Surveill 2002, 7:6I-65.

10. Lopman BA, Adak GK, Reacher MH, Brown DW: Two epidemiologic patterns of norovirus outbreaks: surveillance in England and Wales, 1992-2000. Emerg Infect Dis 2003, 9:7I-77.

II. Vinje J, Koopmans MP: Molecular detection and epidemiology of small round-structured viruses in outbreaks of gastroenteritis in the Netherlands. J Infect Dis 1996, 174:610-615.

12. Villena C, El-Senousy WM, Abad FX, Pinto RM, Bosch A: Group A rotavirus in sewage samples from Barcelona and Cairo: emergence of unusual genotypes. Appl Environ Microbiol 2003 69:3919-3923.

13. Allard A, Albinsson B, Wadell G: Detection of adenoviruses in stools from healthy persons and patients with diarrhea by two-step polymerase chain reaction. I Med Virol 1992, 37:149-157.

14. Guix S, Caballero S, Villena C, Bartolome R, Latorre C, Rabella N, Simo M, Bosch A, Pinto RM: Molecular epidemiology of astrovirus infection in Barcelona, Spain. J Clin Microbiol 2002, 40:133-139.

15. Morsy El-Senousy W, Guix S, Abid I, Pinto RM, Bosch A: Removal of astrovirus from water and sewage treatment plants, evaluated by a competitive reverse transcription-PCR. Appl Environ Microbiol 2007, 73:164-167.

16. Buesa J, Collado B, Lopez-Andujar P, Abu-Mallouh R, Rodriguez DJ, Garcia DA, Prat J, Guix S, Llovet T, Prats G, Bosch A: Molecular epidemiology of caliciviruses causing outbreaks and sporadic cases of acute gastroenteritis in Spain. J Clin Microbiol 2002 40:2854-2859.

17. Kaplan JE, Feldman R, Campbell DS, Lookabaugh C, Gary GW: The frequency of a Norwalk-like pattern of illness in outbreaks of acute gastroenteritis. Am J Public Health 1982, 72:1329-1332.

18. Widdowson MA, Sulka A, Bulens SN, Beard RS, Chaves SS, Hammond R, Salehi ED, Swanson E, Totaro J, Woron R, Mead PS, Bresee JS, Monroe SS, Glass RI: Norovirus and foodborne disease, United States, 199 I-2000. Emerg Infect Dis 2005, I I:95-102.

19. Lynch M, Painter J, Woodruff R, Braden C: Surveillance for foodborne-disease outbreaks--United States, 1998-2002. MMWR Surveill Summ 2006, 55:1-42.

20. van Duynhoven YT, de Jager CM, Kortbeek LM, Vennema H, Koopmans MP, van Leusden F, van der Poel WH, van den Broek MJ: A oneyear intensified study of outbreaks of gastroenteritis in The Netherlands. Epidemiol Infect 2005, 133:9-21.

21. Lindqvist R, Andersson $Y$, Lindback J, Wegscheider M, Eriksson $Y$, Tidestrom L, Lagerqvist-Widh A, Hedlund KO, Lofdahl S, Svensson L, Norinder A: A one-year study of foodborne illnesses in the municipality of Uppsala, Sweden. Emerg Infect Dis 200I, 7:588-592

22. Cowden JM: Winter vomiting. BMJ 2002, 324:249-250.

23. Fankhauser RL, Monroe SS, Noel JS, Humphrey CD, Bresee JS, Parashar UD, Ando T, Glass RI: Epidemiologic and molecular trends of "Norwalk-like viruses" associated with outbreaks of gastroenteritis in the United States. J Infect Dis 2002, 186: I-7.

24. Hedlund KO, Rubilar-Abreu E, Svensson L: Epidemiology of calicivirus infections in Sweden, 1994-1998. J Infect Dis 2000, 18I Suppl 2:S275-S280.

25. Anderson AD, Garrett VD, Sobel J, Monroe SS, Fankhauser RL Schwab KJ, Bresee JS, Mead PS, Higgins C, Campana J, Glass RI: Multistate outbreak of Norwalk-like virus gastroenteritis associated with a common caterer. Am J Epidemiol 200I, 154:1013-1019.

26. Gross TP, Conde JG, Gary GW, Harting D, Goeller D, Israel E: An outbreak of acute infectious nonbacterial gastroenteritis in a high school in Maryland. Public Health Rep 1989, 104:164-169.

27. Gotz H, de Jong B, Lindback J, Parment PA, Hedlund KO, Torven M, Ekdahl K: Epidemiological investigation of a food-borne gastroenteritis outbreak caused by Norwalk-like virus in $\mathbf{3 0}$ daycare centres. Scand J Infect Dis 2002, 34:1| 15-121.
28. Dedman D, Laurichesse H, Caul EO, Wall PG: Surveillance of small round structured virus (SRSV) infection in England and Wales, 1990-5. Epidemiol Infect 1998, I 2 I:139-149.

29. Koopmans M, Duizer E: Foodborne viruses: an emerging problem. Int J Food Microbiol 2004, 90:23-4I.

30. de Wit MA, Koopmans MP, van Duynhoven YT: Risk factors for norovirus, Sapporo-like virus, and group A rotavirus gastroenteritis. Emerg Infect Dis 2003, 9:1563-1570.

31. Koopmans M, Vinje J, de Wit M, Leenen I, van der Poel WC, van Duynhoven Y: Molecular epidemiology of human enteric caliciviruses in The Netherlands. J Infect Dis 2000, I8I Suppl 2:S262-S269.

32. Barker J, Vipond IB, Bloomfield SF: Effects of cleaning and disinfection in reducing the spread of Norovirus contamination via environmental surfaces. J Hosp Infect 2004, 58:42-49.

33. Maunula $\mathrm{L}$, von Bonsdorff $\mathrm{CH}$ : Norovirus genotypes causing gastroenteritis outbreaks in Finland 1998-2002. J Clin Virol 2005 , 34:186-194.

34. Blanton LH, Adams SM, Beard RS, Wei G, Bulens SN, Widdowson MA, Glass RI, Monroe SS: Molecular and epidemiologic trends of caliciviruses associated with outbreaks of acute gastroenteritis in the United States, 2000-2004. J Infect Dis 2006, 193:413-421.

35. Duizer E, Pielaat A, Vennema H, Kroneman A, Koopmans M: Probabilities in norovirus outbreak diagnosis. J Clin Virol 2007, 40:38-42.

\section{Pre-publication history}

The pre-publication history for this paper can be accessed here:

http://www.biomedcentral.com/1471-2334/8/47/prepub
Publish with Bio Med Central and every scientist can read your work free of charge

"BioMed Central will be the most significant development for disseminating the results of biomedical research in our lifetime. "

Sir Paul Nurse, Cancer Research UK

Your research papers will be:

- available free of charge to the entire biomedical community

- peer reviewed and published immediately upon acceptance

- cited in PubMed and archived on PubMed Central

- yours - you keep the copyright
BioMedcentral 